\title{
Growth and pigmentation development efficiencies in fantail guppy, Poecilia reticulata fed with commercially available feeds
}

\author{
1 \& 2 Banani Mandal, ${ }^{2}$ Arunava Mukherjee and ${ }^{2}$ Samir Banerjee \\ ${ }^{1}$ Jogesh Chandra Chaudhuri College, 30 Prince Anwar Shah Road, Kolkata-700033 \\ ${ }^{2}$ Aquaculture Research Unit , Department of Zoology, University of Calcutta, \\ 35, Ballygaunge Circular Road, Kolkata-700019
}

\begin{abstract}
The commercial value of ornamental fish is primarily dependent on their external body colouration. Fade coloured fish fails to attract the interest of the buyers. In the present study an experiment were conducted to evaluate the efficacy of four types of feed (Living tubifex, Dried tubifex, Dried Daphnia and Prepared granulated feed) in the rearing of fantail guppy. Carotenoid content of the feed used, caudal fin and muscle of the fish and specific growth rate (SGR) of the fish were also analyzed. Results showed that the fantail guppy utilized the live organisms more efficiently than the artificial diet. Results are also encouraging because the fantail guppy became more brightly colourful which fed the carotenoid rich feed in comparison to the types of feed. Living tubifex was proved to be the best feed for guppy for increasing the growth and colouration.
\end{abstract}

Keywords: Ornamental fish, carotenoids, fish feed, guppy, SGR

\section{INTRODUCTION}

Ornamental fish farming is among the most valuable industries in the recent times. Ornamental fishes are often referred as living jewels due to their colour, shape and behaviour. They are peaceful, generally tiny, attractively coloured and could be accommodated in confined spaces. Modern ornamental fish culture and breeding operations, have become vertically and horizontally intensified, necessitating a continuous supply of nutritionally balanced, cost-effective feed. Approximately $75 \%$ of the freshwater aquarium fish imported into the United States originate from Southeast Asia (Chapman et al. 1997). In contrast to the culture of edible fish, information on the dietary requirements and feeding practices of ornamental fish is

limited (NRC, 1993). The guppy Poecilia reticulata is considered to be the most popular aquarium fish (Whitern, 1979). Knowledge of ornamental fish nutritional requirements has evolved primarily from experiences of individual farmers (Socolof, 1980). Various live organisms have been used for rearing larval fish. Chironomus larvae are an excellent food source for various fish species, particularly the carnivorous aquarium fishes such as the Siamese fighting fish, Oscar, Discus and Cichlids (Shim, 1986). Tubifex has long been known to enhance growth and reproduction in some aquarium fishes (Shim, 1986). In fresh water ornamental fish culture, Moina used to be the most common live feed organism for feeding young fish in the industry (Lim et al, 2001).Literature review indicated that ornamental fish require between 50 and $400 \mathrm{mg} / \mathrm{L}$ of synthetic or natural carotenoids (e.g., red pepper and marigold extracts) in their diet to develop color similar to those of fish eating live foods (Boonyaratpalin and Lovell, 1977; Fey and Meyers, 1980; Lovell, 1992). Although the ornamental fish industry is one of the most valuable agricultural commodities in the country, there is little published information on feeding practices.

Some species, such as the ruby barb (Puntius nigrofasciatus), a voracious and indiscriminate feeder, prefers live feed to artificial feeds (Weerasooriya et al., 1999).Ornamental fish in captivity need to utilise their dietary protein with the utmost efficiency, as the breakdown products of protein metabolism (mainly ammonia) will directly pollute their living environment (Pannevis, 1993; $\mathrm{Ng}$ et al., 1993; Earle, 1995; Pannevis and Earle, 1995). As fish cannot synthesize these pigments, they rely on dietary supply of carotenoids to achieve their natural skin pigmentation, one of the most important quality criteria informing the market value of ornamental fish (Pariapatananont et al, 1999; Lovell, 2000; Gouveia et al, 2003). The conspicuousness of the carotenoid- based colouration is considered as a reliable indicator of the foraging ability of individuals for carotenoid- rich foods (Endler, 1980). The present paper tries to communicate the efficacy of different 
commercially available feed and a live feed for better growth and colouration.

\section{MATERIALS AND METHODS}

Fantail guppies with red caudal fin of more or less uniform size $(2.755 \mathrm{~cm}$ in length and $289 \mathrm{mg}$ in weight) of 20 days age were obtained from an ornamental fish farmer and acclimatized in the well maintained aquaria for 7 days prior to beginning the experiment. Aquaria were numbered as $A, B, C$ and $D$ respectively and each of which contained 10 fishes. Dried Tubifex, Living Tubifex, Dried Daphnia and prepared granulated feed (Commercial name Tokyo) were given as once on alternate day. The experiment was conducted for a period of 90 days. Total carotenoid estimation in the caudal fin and muscle of the fish was carried out prior to the start of the experiment and after the termination of the experiment following BioAstin/ Naturose ${ }^{\mathrm{TM}}$ Technical Bullatin \# 020, 2001)Following this procedure carotenoid and astaxanthin quantity was measured from the different types of feed used in the experiment. For the comparison of growth pattern, SGR (Ezhil et al, 2008) of each of the fishes measured at the termination of the experiment.

\section{RESULT AND DISCUSSION}

In the experiment we used four types of fish feeds. During the time of the experiment better foraging ability was observed in the order of the aquarium number $B>C>A>D$. At the end of the experiment better growth in terms of body length and weight was also found in the above order (Table 1). Specific growth rate (SGR) of the fish followed the same order of $B>C>A>D$ (Table 1). It was also found that the SGR of the fish that fed living tubifex was significantly higher than the fishes of the aquaria. At the end of the experiment we estimated the approximate astaxanthin values from the muscles and caudal fins of the fish of the studied aquaria. Result showed most approximate astaxanthin value in the aquarium $B$ than the aquarium $C$ than the aquarium $A$ and $D$. (Figure 2).

When we estimated the approximate astaxanthin of the fish feeds, living tubifex showed more astaxanthin content in comparison to the other feeds (Figure 1). The order of approximate astaxanthin content of the other fish feeds was Granulated feed (Tokyo) > Dried Tubifex > Dried Daphnia. Fish metabolizes carotenoids before depositing them onto natural receptors in the skin (Miki et al, 1985; Matsuno et al, 1985; Katsuyama et al, 1987; Katsuyama and Matsuno, 1988). The great amount of astaxanthin in the caudal fin and muscle of the fantail guppy that fed living tubifex is significantly related to the amount of astaxanthin present in that feed. The present work may increase the interest and selling trade of common ornamental fish farmers.

Table 1: Mean total length and weight of Poecilia reticulata fed with different types of feed.

\begin{tabular}{|c|c|c|c|c|c|}
\hline Tank & $\begin{array}{l}\text { Length ( } \pm \text { ) } \\
(\mathrm{cm})\end{array}$ & $\begin{array}{l}\text { \% increase in } \\
\text { length }\end{array}$ & $\begin{array}{l}\text { Weight (士) } \\
\text { (mg) }\end{array}$ & $\%$ increase in weight & SGR \\
\hline Initial & $2.55 \pm 0.074$ & & $0.186 \pm 0.022$ & & \\
\hline Dried Tubifex & $2.9 \pm 0.141$ & 13.75 & $0.224 \pm 0.0167$ & 20.43 & 0.042 \\
\hline Living Tubifex & $3.25 \pm 0.169$ & 27.45 & $0.282 \pm 0.022$ & 51.61 & 0.107 \\
\hline Tokyo & $3.0 \pm 0.253$ & 17.65 & $0.236 \pm 0.0191$ & 20.88 & 0.056 \\
\hline Dried Daphnia & $2.68 \pm 0.144$ & 5.10 & $0.215 \pm 0.016$ & 15.59 & 0.032 \\
\hline
\end{tabular}




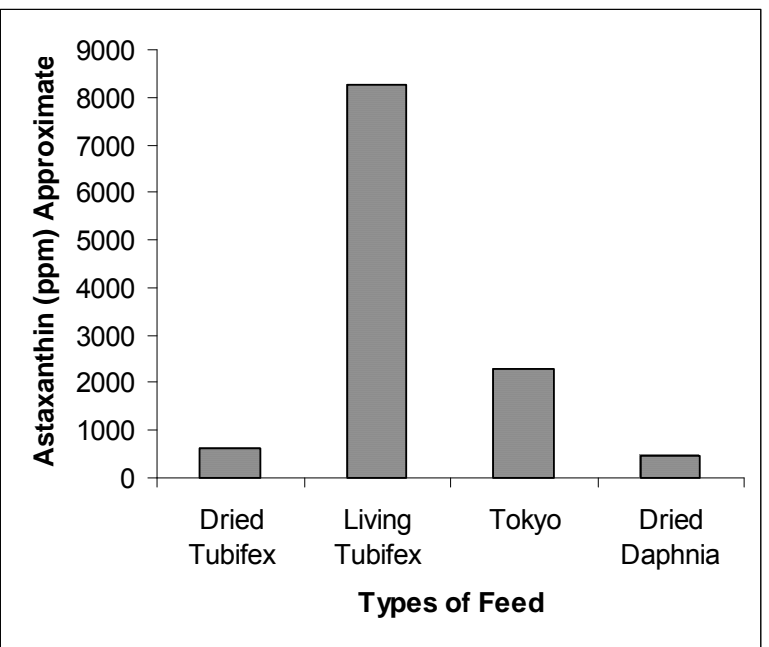

Fig 1: Amount of approximate astaxanthin different types of feed used in the experiment.

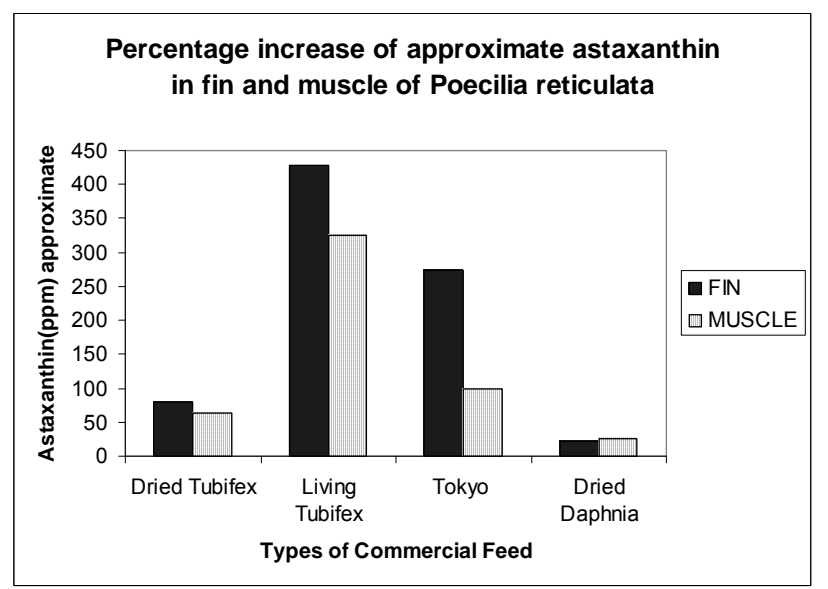

Fig 2: Percentage increase of approximate astaxanthin in fin and muscle of Poecilia reticulata fed with different types of feed at the time of termination of the experiment.

\section{REFERENCES}

Arunachalam, S. And Reddy, S.R. 1981. Interactions of feeding rates on growth, food conversion and body composition of the freshwater catfish Mystus vittatus (Bloch). Hydrobiologia 78: 25-32.

BioAstin/ Naturose ${ }^{\mathrm{TM}}$ Technical Bulletin- 020, Revision Date: November 9, 2001. Boonyaratpalin, M. and Lovell, R.T. 1977. Diet preparation for aquarium fishes. Aquaculture 12:53-62.
Chapman, F.A., Fitz-Coy, S.A., Thunberg, E.M. and Adams, C.M.1997. United States of America trade in ornamental fish. Journal of the World Aquaculture Society. 28:1-10.

Earle, K.E., 1995. The nutritional requirements of ornamental fish. Vet. Q.17 (Suppl. 1), S53-S55.

Endler, J. A. 1980. Natural selection on color patterns in Poecilia reticulata. Evolution 34: 76-91.

Fermin, A. C., Bolivar, M. E., 1991. Larval rearing of the Philippine freshwater atfish, Clarias macrocephalus (Gunther), fed live zooplankton and artificial diet: a preliminary study. Isr. J. Aquacult.-Bamidgeh 43: 8794.

Fey, M.and Meyers, S.P. 1980. Evaluation of carotenoidfortified flake diets with pearl gourami Trichogasler leeri. Journal of Aquariculture 1:15- 19.

Gouveia, L., Rema, P., Pereira, O., Empis, J., 2003. Colouring ornamental fish (Cyprinus carpio and Carassius auratus) with microalgal biomass. Aquac. Nutr. 9: 123-129.

Hata, M., Hata, M., 1972. Carotenoid pigments in goldfish. IV. Carotenoid metabolism. Bull. Jpn. Soc. Sci. Fish. 38: 331-338.

Hata, M., Hata, M., 1973. Carotenoid pigments in goldfish.V. Conversion of zeaxanthin to astaxanthin. Bull. Jpn. Soc. Sci. Fish. 38: 339-343.

Hata, M., Hata, M., 1976. Carotenoid metabolism in fancy red carp, Cyprinus carpio. II. Metabolism of 14Czeaxanthin. Bull. Jpn. Soc. Sci. Fish. 42: 203-205.

Katsuyama, M., Komori, T. and Matsuno, T. 1987. Metabolism of three stereoisomers of astaxanthin in the fish, rainbow trout and tilapia. Comp. Biochem. Physiol. 86B: 1- 5.

Katsuyama, M. and Matsuno, T. 1988. Carotenoid and vitamin $A^{*}$, and metabolism of carotenoids, $\beta$ carotene, canthaxanthin, astaxanthin, zeaxanthin, lutein, and tunaxanthin in tilapia Tilapia nilotica. Comp. Biochem. Physiol. 90B: 131-139.

Lim, L.C., Sho, A., Dhert, P. and Sorgeloos, P., 2001. Production and application of on-grown Artemia in freshwater ornamental fish farm. Aquac. Econ. Manage. 5: 211-228.

Lovell, R.I. 1992. Dietary enhancement of color in ornamental fish. Aquaculture Magazine 18(5):77-79.

Lovell, R.T., 2000. Nutrition of ornamental fish. In: Bonagura, J. (Ed.), Kirk's Current Veterinary Therapy XIII-Small Animal Practice. W.B. Saunders, Philadelphia, USA, pp. 1191-1196.

Matsuno, T., Katsuyama, M.., Maoka, T., Hirono, T. and Komori, T. 1985. Reductive metabolic pathways of 
carotenoids in fish (3S, 3'S)-astaxanthin to tunaxanthin A, B and C. Comp. Biochem. Physiol. 80B: 779- 789.

Miki, W., K. Yamaguchi, S. Konosu, T. Takane, M. Satake, T. Fujita, H. Kuwabara, S. Shimeno and M. Takeda. 1985. Origin of tunaxanthin in the integument of yellowtail (Seriola quinqueradiata). Comp. Biochem. Physiol. 80: 195-201

Ng,W.J., Kho, K., Sim, T.S., Ho, J.M. and Tay, S.H., 1993. Preliminary estimation of tropical ornamental fish metabolite production rates. Aquaculture 110: 263269.

No, H.K. and Storebakken, T.1991. Color stability of rainbow trout fillets during frozen storage. J. Food Sciences, 56: 969-972.

NRC. 1993. Nutrient Requirements of Fish. National Research Council, National Academy Press, Washington, D.C

Pannevis, M.C., 1993. Nutrition of ornamental fish. In: Burger, I.H. (Ed.), The Waltham Book of Companion Animal Nutrition. Pergamon Press, Oxford, pp. 85-96.

Pannevis, M.C. and Earle, K.E., 1995. Nutrition of ornamental fish. Wien. Tierärztl. Mnschr. 82: 96-99 (German with English abstract).
Paripatananont, T., Tangtrongpairoj, J., Sailasuta, A. and Chansue, N., 1999. Effect of astaxanthin on the colouring of goldfish Carassius auratus. J. World Aquac. Soc. 30: 454-460.

Shim, K. F., 1986: By-product utilization in live food culture for tropical aquarium fish. In: Finfish Nutrition Research in Asia. S. S. De Silva (Ed.) Proceedings of the Second Asian Fish Nutrition Network Meeting. Asian Fisheries Society, Manila, Philippines, pp. 42-47.

Socolof, R. 1980. Tropicals. Pages 163-206 in E.E. Brown and J.B. Gratzek, eds. Fish Farming Handbook: Food, Bait, Tropicals and Goldfish. AVI Publishing Co., Westport, Connecticut.

Torrisen, O.J., Hardy, R.W.and Shearer, K.D. 1989. Pigmentation of salmonids- carotenoid depositions and metabolism.CRC, Aquatic Sciences, 1(2): 209-225.

Weerasooriya, A.C., Edirisinghe, U., Silva, P., Dematawewa, C.M.B., 1999. Feeding behaviour and acceptability of different feeds by Puntius nigrofasciatus. Trop. Agric. Res. 11, 221-228.

Whitten, W.A. 1979. Livebearers. Tropical Fish Hobbyist Publications, Inc. Neptune City, New Jersey, USA.. 93 pp.

Winfree, R.A. 1989. Tropical fish. World Aquaculture 20(3):24-30. 